\title{
Genetic correlation and path analysis of agronomical traits of soybean (Glycine max) lines infected by CpMMV
}

\author{
MARIA MONICHA FAOT ${ }^{1}$, SITI ZUBAIDAH ${ }^{2, \bullet}$, HERU KUSWANTORO $^{3,, v}$ \\ ${ }^{1}$ Graduate School, Universitas Negeri Malang. Jl. Semarang No 5, Sumbersari, Malang 65145, East Java, Indonesia. \\ ${ }^{2}$ Department of Biology, Faculty of Mathematics and Natural Sciences. Universitas Negeri Malang. Jl. Semarang No. 5, Sumbersari, Malang 65145, East \\ Java, Indonesia. Tel./fax.: +62-341-551312, "email: siti.zubaidah.fmipa@um.ac.id \\ ${ }^{3}$ Indonesian Legume and Tuber Crops Research Institute, Indonesian Agency for Agricultural Research and Development. Jl. Raya Kendalpayak Km. 8, \\ Kendalpayak, Pakisaji, Malang 65101, East Java, Indonesia. Tel./fax.: +62-341-801496, "email: herukusw@gmail.com
}

Manuscript received: 6 March 2019. Revision accepted: 2 May 2019.

\begin{abstract}
Faot MM, Zubaidah S, Kuswantoro H. 2019. Genetic correlation and path analysis of agronomical traits of soybean (Glycine $\max )$ lines infected by CpMMV. Biodiversitas 20: 1496-1503. CpMMV is a virus that can decrease soybean production. The virus vector is an insect where the control is carried out using a chemical insecticide that is less environmentally friendly. Developing a superior variety of soybean that is resistant to CpMMV is one of the solutions to solve such a problem. This research aimed to study the relationship of agronomical traits to the yield of soybean line infected by CpMMV. Ten lines and two varieties of soybean with four replications was used in this study in a randomized complete block design. Bemisia tabaci was used in CpMMV infestation as the vector of the disease. Rearing Bemisia tabaci was done forty days before sowing the main experiment, and it placed surrounding the main experiment plots. The observation variables were disease severity, days to flowering and maturity, plant height, length, width and ratio of the leaf, number of branches and reproductive nodes, number of filled and unfilled pods, number of seeds, 100 seeds weight, and seed yield per plant. The data was analyzed for genotypic and phenotypic correlation, and the path analysis for direct and indirect effects of disease severity, and agronomical characters. The results showed that CpMMV infestation caused disease severity by about 20-28.5\%. A significant positive phenotypic correlation to the seed yield per plant was shown by the number of reproductive nodes and the 100 seeds weight. Meanwhile, a significant positive genotypic correlation to the seed yield per plant was shown by the days to maturity and the number of branches. The number of reproductive nodes, the 100 seeds weight, and the number of seeds per plant showed a high direct effect to the seed yield per plant. The high positive indirect effect was also shown by the number of filled pods, days to flowering, plant height, leaf length, leaf width, the number of reproductive nodes, and the number of branches through the number of seeds per plant was also. Therefore, the selection criteria for high yielding CpMMV-resistant soybean lines can be based on the number of reproductive nodes and 100 seeds weight.
\end{abstract}

Keywords: CpMMV, genetic correlation, path analysis

\section{INTRODUCTION}

The emergence of various pathogens along with the increase in cropping index results in barriers to soybean production. One of the diseases that often attack soybean plants is viruses, including cowpea mild mottle virus (CpMMV). This virus naturally has a host on the species Fabaceae (Laguna et al. 2006). The host, season and the viral strain influence the symptoms of CpMMV (Menzel et al. 2010; Zanardo et al. 2014). Apart from the increasing cropping index, this virus often attacks because of the absence of climate barriers such as in the subtropical region. Poor crop rotation also results in viruses remaining in the field (Zanardo 2017). In soybean, the symptoms of CpMMV are highly variable than other hosts. The symptomless CpMMV infections in some soybean varieties have also been reported by some author (Almeida et al. 2005; Zanardo et al. 2014). The symptomless infections associated with the nonpersistent whitefly transmission (Zanardo 2017).

The yield of soybeans attacked by the virus can decrease up to $90 \%$, depending on the age of the plant when infected, viral strains, and environmental conditions.
Kuswantoro et al. (2008) reported disease severity variation of CpMMV attacks on 21 soybean germplasm from 16 regencies in East Java ranging from 30.6-71.1\% with seed yield decrease reaching $53.9-99.4 \%$. This high yield loss is due to soybean susceptible genotypes undergo flower dropping and poor development of the pods. Severe deformation of the seeds and reduction of the weight of the seed are observed on the infected plants (Rodrigues 2014). The stem necrosis that found on the plant (Arias et al. 2015) is also able to inhibit the process of nutrients uptake as the raw materials for photosynthesis. In addition, the occurrence of disturbances in the leaves such as mottling in the leaves (Zubaidah and Kuswantoro 2016) can also interfere with the process of photosynthesis.

Grain yield is a complex trait and associates with other traits. This trait expresses many factors and the results of their interaction (El-Mohsen et al. 2013; Silva et al. 2015). The degree of this interaction can be studied through genetic correlation to identify the beneficial traits in a selection for optimum genetic gains ( Silva et al. 2015). Correlations between traits allow simultaneous changes in one or more agronomic traits based on a single trait selection (Barbosa et al. 2016). In plant breeding, the 
correlation can be based on phenotypic, genotypic, or environmental nature. Genetic and environmental factors are involved in phenotypic correlation, where the use of this correlation will interfere with the obtaining of the target traits. Genetic correlation involves a relationship of heritable nature that allows heritable selection between the traits. Therefore, the study of genetic correlation is crucial to identifying the traits that can be used as an indirect selection for grain yield (Machado et al. 2017).

The information of genetic variability and relationship of yield component traits with seed yield are needed in direct selection to avoid misleading in selection by dividing genotypic correlation coefficients into direct and indirect effects (Balla and Ibrahim 2017). Direct and indirect effects of traits can be distinguished by path analysis to find out the basic or main traits that relate to the desired trait. The misleading is also can be caused by miscorrelation due to unnecessarily cause and effect relationship. The miscorrelations between two traits can be identified by path analysis using the effect of the third trait (Barbosa et al. 2016). Therefore, path analysis is an important tool to find out a trait that correlates tightly with the seed yield.

\section{MATERIALS AND METHODS}

\section{Study sites}

This study was conducted at Jambegede Research Station, Malang, East Java, Indonesia at the coordinate of $08^{\circ} 11^{\prime} 02^{\prime \prime} 112^{\circ} 33^{\prime} 32,9^{\prime \prime}$.

\section{Plant materials}

The plant materials were ten soybean lines (UM4-1, UM7-2, UM2-4, UM7-6, UM6-2, UM6-3, UM3-2, UM6-1, UM7-3, UM3-4) and two soybean varieties (Wilis and Gumitir).

\section{Design and cultural practice}

The study was conducted by using randomized complete blocks designs with four times of replications. For each line, there were four rows with $3 \mathrm{~m}$ length. To prevent the seedling fly-pests, the seed was applied with $12.5 \mathrm{~g}$ carbosulfan per $\mathrm{kg}$ seed. This pesticide was employed before planting. The fertilizers of $50 \mathrm{~kg} \cdot \mathrm{ha}^{-1}$ Urea, $75 \mathrm{~kg} \cdot \mathrm{ha}^{-1} \mathrm{SP} 36$, and $75 \mathrm{~kg} \cdot \mathrm{ha}^{-1} \mathrm{KCl}$ were used to provide nutrient for the plant. Weeding was carried out manually at 3,6 and 9 weeks after planting.

\section{Pest infestation}

CpMMV infestation was applied by using Bemisia tabaci as the vector of CpMMV. Forty days before planting the main experiment, Bemisia tabaci was reared naturally on the field surrounding the main experiment plots. When the seedling emerged, the Bemisia tabaci migrated to this seedling causing natural CpMMV infestation.

\section{Observation}

The agronomical traits such as days to flowering and maturity, plant height, length, width and ratio of leaf, number of branches and reproductive nodes, number of filled and unfilled pods, number of seeds, 100 seeds weight, and seed yield per plant, were observed at harvesting, except the days to flowering which was done at the $50 \%$ of the plants was flowering. The days to maturity was taken based on the period from the early planting to the days to maturity after $90 \%$ flowering. The CpMMV disease severity was done at 35 days after planting. The scoring followed the scoring procedure developed by Zubaidah and Kuswantoro (2006).

\section{Data analysis}

The data was obtained from the correlation and path analysis for the direct and indirect effects of disease severity and the agronomical characters based on Singh and Chaudary (1979).

\section{RESULTS AND DISCUSSION}

\section{Performance of agronomical characters}

The disease severity that occurs in the tested genotype ranged from $20.00-28.50 \%$. The highest disease severity was achieved by G10, while the lowest was achieved by G9, G11 (Wilis) and G12 (Gumitir) (Figure 1). Wilis as a moderate resistance variety in this study had a disease severity of $20 \%$ equivalent to the Gumitir as the susceptible variety which reached $20.7 \%$. The low disease severity on Gumitir may be due to the emergence of a new strain, so that the virus was not able to cause disease severity as on Anjasmoro, the variety which was used for the rearing of the Bemisia tabaci. CpMMV has many strains with a different effect on the plant. Two strains of CpMMV were reported to have different disease severity, namely CpMMV-S and CpMMV-M (Naidu et al. 1998). Zanardo et al. (2014) also reported six different strains based on biology and molecular characterization.

Days to flowering varied with the soybean genotypes tested. G9 was the line with the highest plant height followed by G2 and G3 (Figure 2). The lines with the earliest days to flowering were G1, G12, G10, and G1. Days to flowering in soybeans did not change by the existence of CpMMV (Kuswantoro et al. 2014). However, the days to flowering of Wilis and Gumitir in this study was 37 days (Figure 2) different from the description of the varieties where the flowering age of Wilis and Gumitir were 39 and 32 days, respectively (Iletri 2017). The pattern of days to maturity of plants was similar to the days to flowering, where plants with late flowering also have a late maturity (Figure 2). In this study G11 and G12 which are varieties that have days to maturity $85-90$ and 81 days (Iletri 2017) became 85 and 86 days. Days to maturity is strongly influenced by the environment where in good environmental conditions with water, soybeans tend to have a long life. In soybeans attacked by pests, the symptoms of green stem syndrome usually occur where soybean stems remain green (Hobbs et al. 2006).

The highest plant height was achieved by G4, while the lowest is achieved by G7 (Figure 3). Wilis (G11) and Gumitir (G12) also included as the lowest plant. The plant 
height in this study was relatively normal even though the plant experienced a CpMMV attack. Infection to CpMMVsusceptible genotypes can result in stunting plants (Arias et al. 2015; Zubaidah and Kuswantoro 2017). In this study, the disease severity reached an average of $23 \%$, where this was not a severe attack that can result in stunting plants.

The leaf length of the genotype tested was significantly different, where $\mathrm{G} 2$ is the genotype that has the longest leaf length $(13 \mathrm{~cm})$, while $\mathrm{G} 1$ is the genotype that has the shortest leaf length $(12 \mathrm{~cm})$ (Figure 4). This is not similar to the width of the leaf, where there was not significantly different among the genotypes. Both of these leaf characters contribute to leaf ratios. Leaf ratios that close to 1 indicate that the leaves shape are round. In this study, there were no round leaves. Based on the Chen and Nelson (2004) classification of soybeans tested had an oval shape, i.e., the ratio of length/width was less than 2 .

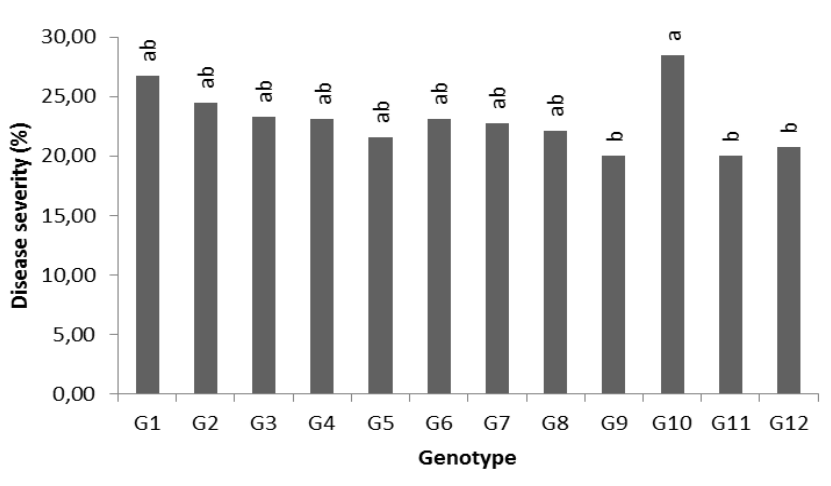

Figure 1. Disease severity of soybean genotypes

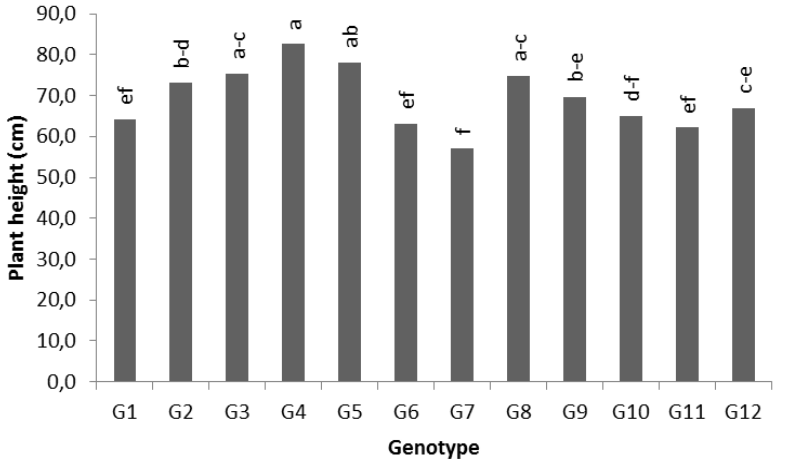

Figure 3. Plant height of soybean genotypes

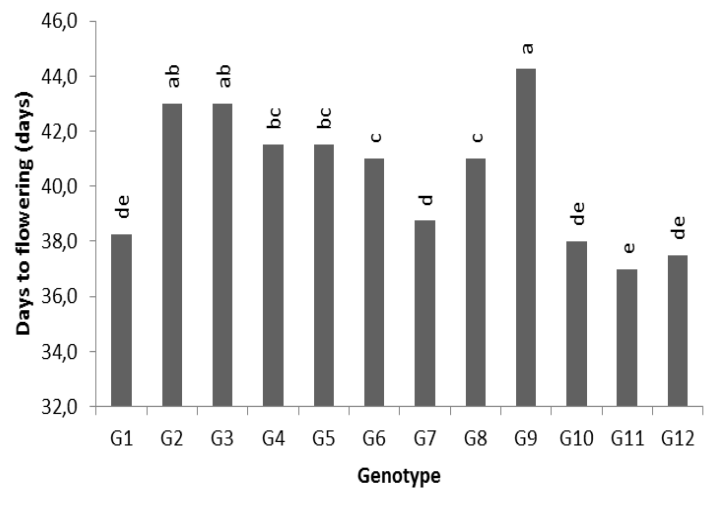

$\mathbf{A}$

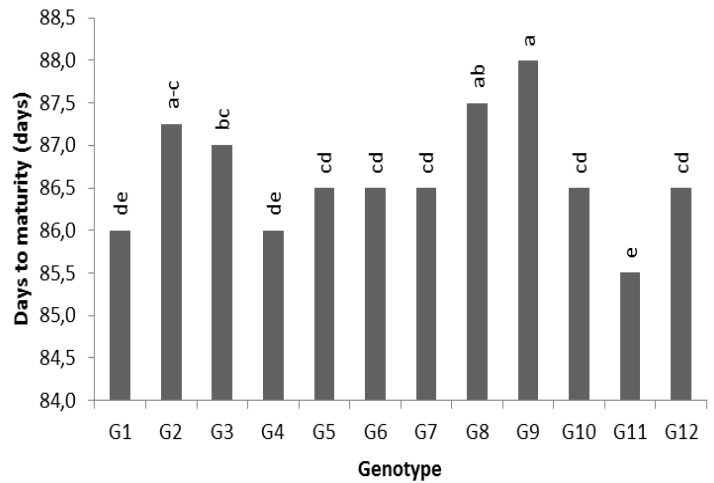

B

Figure 2. Days to flowering (A) and days to maturity (B) of soybean genotypes

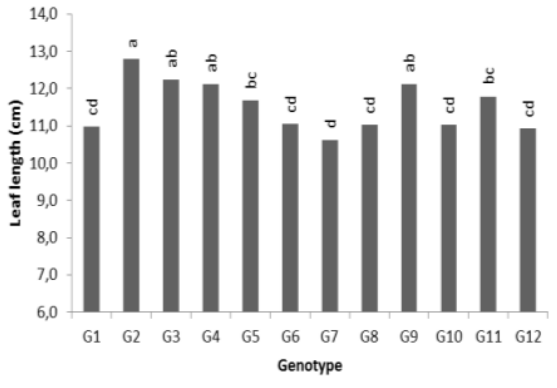

A

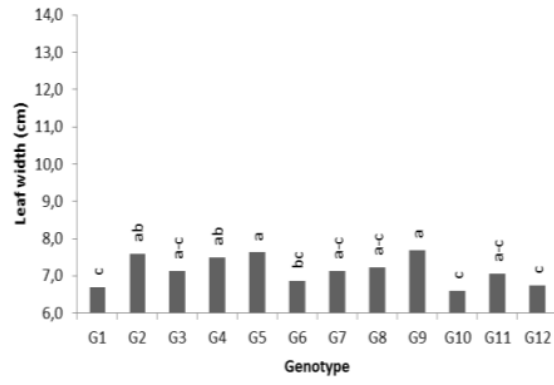

B

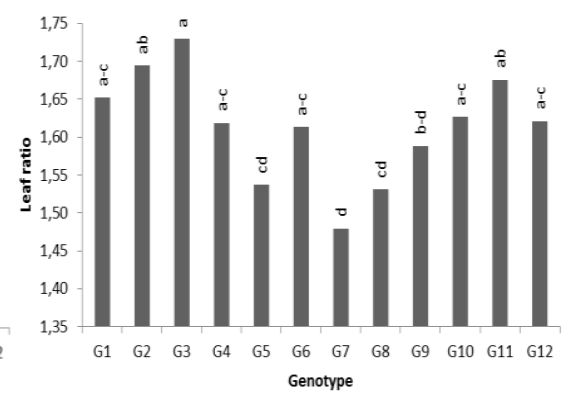

C

Figure 4. Leaf length (A), leaf width (B), and leaf ratio (C) of soybean genotypes 
The pattern of the number of branches of the genotype tested is similar to the number of reproductive nodes, where G7 showed the lowest number of branches and reproductive nodes (Figure 5). The number of branches per plant is influenced by plant density, where the branch variability correlates with plant spacing (Agudamu et al. 2016). At low plant densities, branches can develop optimally, while at high densities the branches do not develop. In this study, plants were planted on the spacing of $40 \mathrm{~cm} \times 15 \mathrm{~cm}$ so that branches could develop optimally. Reproductive nodes of plants are located on the main stem and branches of plants. Increasing branches of plants led to an increase in the number of reproductive nodes. The lower planting density allows branch seed yield to be larger than the main stem seed yield (Agudamu et al. 2016). The variability in the main stem and branch seed yields can be used as a criterion to find out a genotype for narrow or wide rows (Norsworthy and Shipe 2005).

The highest number of pods is shown by G5, G3, and G4, while G1 showed the lowest number of filled pods. The pattern of the number of filled pods is similar to the number of unfilled pods, where genotypes with a large number of filled pods also had a large number of unfilled pods. This indicates that soybeans with large numbers of filled pods also have the opportunity for more unfilled pods. However, there was one genotype (G7) which had many unfilled pods but the pod's size are relatively small (Figure 6). The number of unfilled pods on the G7 may be affected by the CpMMV infection. The small pod is produced when susceptible varieties are infected at begining of growth (Sinclair 1993). Sutrisno and Kuswantoro (2016) reported that moderate resistance variety had more pods number than the resistance variety.

The number of seeds per plant is an important component because it determines the yield of seeds per plant. The highest number of seeds was reached by G2 and G5, namely 134 and 133 seeds, while the lowest was reached by G1 and G7 which reached 68 and 74.1 seeds. Disease in plant increase a flower abortion (Hartman et al. 2015), consequently, decreasing seed number. The size of seeds measured by the weight of 100 seeds indicates that G11 and G12 have the highest weight of 100 seeds. Most genotypes that have a large number of seeds have low seed size. The infected plant also experiences seed deformation (Hartman et al. 2015) and seeds weight reduction (Rodrigues 2014). In this study, we got a genotype that has the lowest number of seeds also has the lowest weight of 100 seeds like G7 (Figure 7).

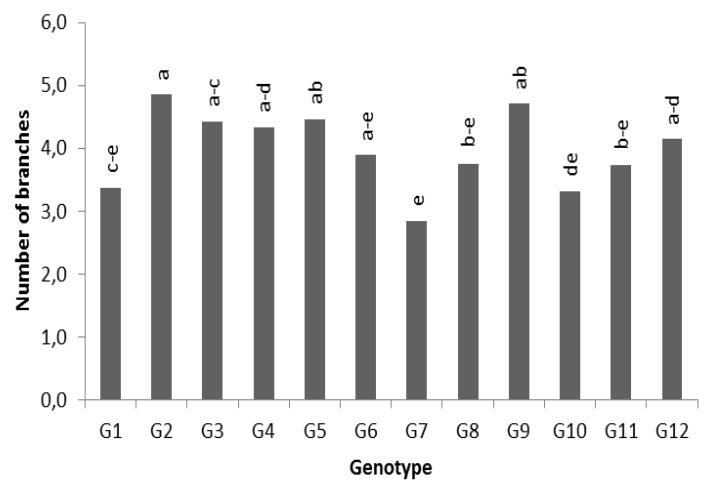

A

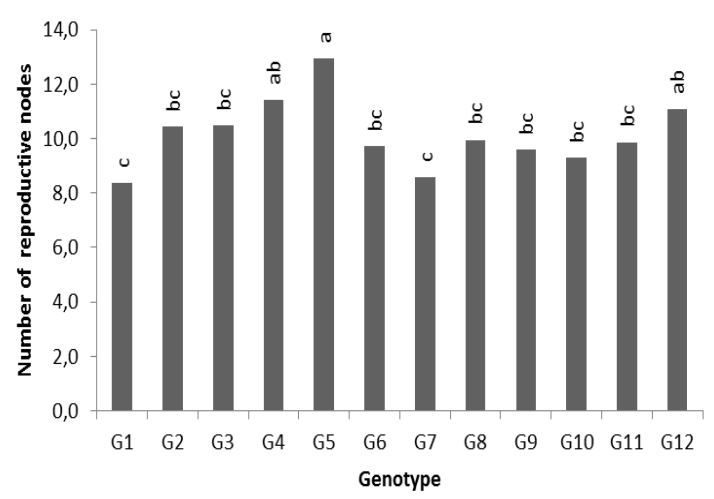

B

Figure 5. Number of branches (A) and number of reproductive nodes (B) of soybean genotypes

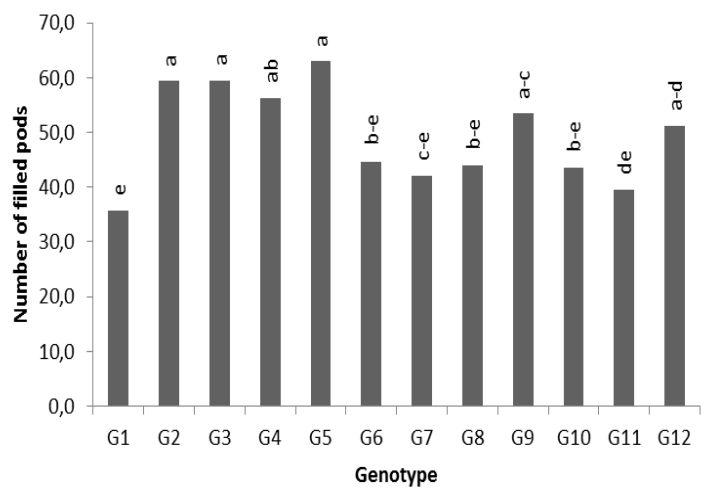

A

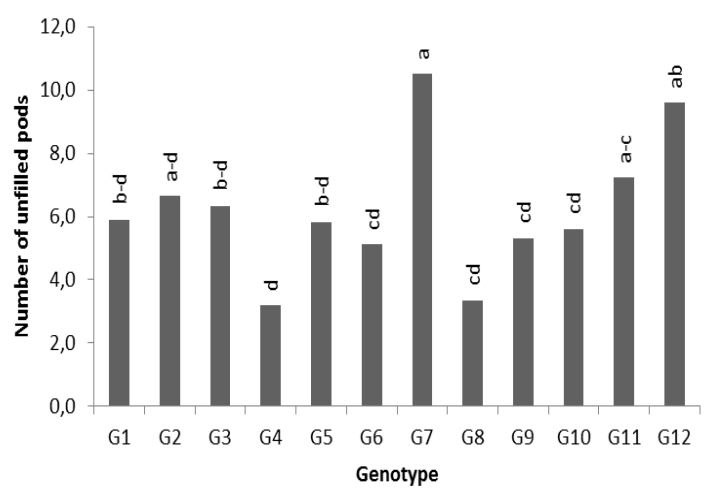

B

Figure 6. Number of filled pods (A) and unfilled pods (B) of soybean genotypes 


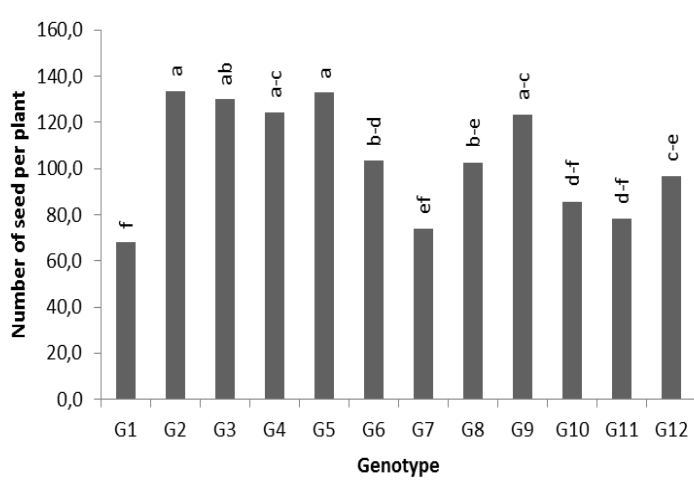

A

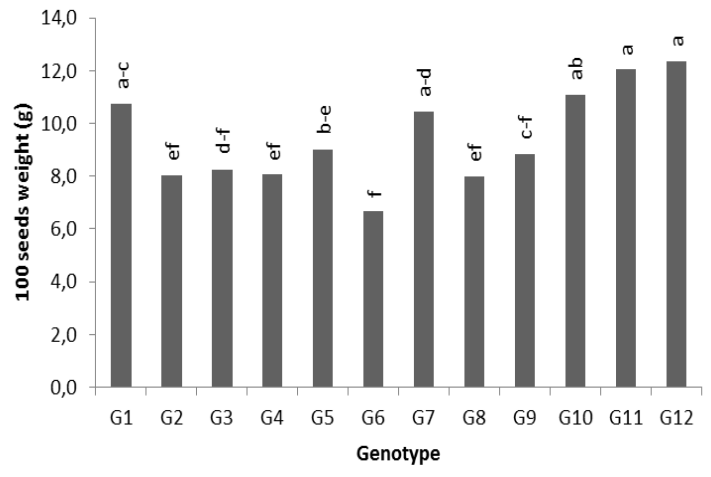

B

Figure 7. Number of seeds per plant (A) and 100 seeds weight (B) of soybean genotypes

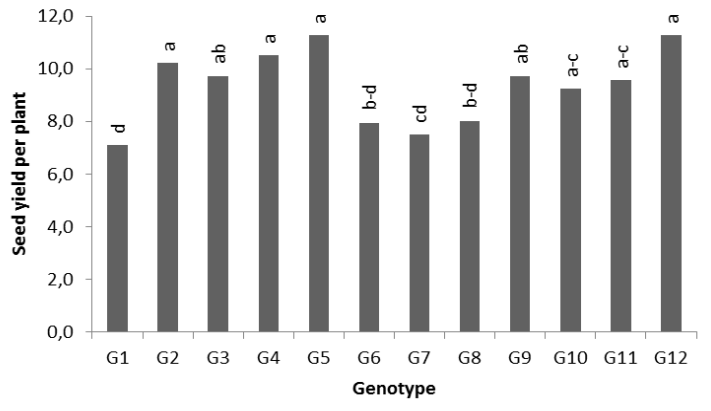

Figure 8. Seed yield per plant of soybean genotypes

The seed yield is a combination of various yield components, especially the number of seeds and the size of seeds. Seed yields per plant differ significantly between genotypes. The yield of seeds per plant has a pattern similar to the size of seeds rather than the number of pods and the number of seeds per plant. However, the G1 genotype which had a relatively large seed size from the tested genotype, had the lowest seed yield because it had the lowest number of seeds per plant (Figure 8). Kuswantoro et al. (2014) also reported similar results in testing CpMMV-resistant soybean lines in two different fields.

\section{Correlation among agronomical characters}

The agronomical character presented in Table 1 had a significant positive genotypic correlation between days to maturity and leaf length. In the phenotypic correlation, such characters also had a significant and high correlation. The positive value showed that the days to maturity had an in line correlation to the leaf length. This case means that the increase of the days to maturity was followed by the increase of the leaf length. Meanwhile, the leaf ratio and the 100 seeds weight had a significant and low genotypic correlation. This case means that the increase in leaf ratio was followed by an increase of 100 seeds weight. It was in line with Gardner et al. (1991) stating that the larger the leaf of the plant, the leaf will get much more sunlight. The product of leaf photosynthesis was in the form of photosynthate, and it was used for the growth of a generative organ, for examples the process of bloom and seed forming.

The days to flowering and days to maturity had a positive and low phenotypic correlation. This case means the increase of days to flowering was followed by an increase of days to maturity. This case was also in line with Arshad et al. (2006) and Alakhder et al. (2015) stating that the days to flowering had a positive correlation to the days to maturity. The process of the flower forming until the mature seed correlated with other reproductive traits, since they were the parts of generative growth (Fehr and Caviness 1977). Based on that case, the days to maturity of soybean was influenced by the days to flowering (Table 1).

The highest negative genotypic correlation was shown by the 100 seeds weight and the disease severity. This case means that the increase of 100 seeds weight was followed by a decrease in disease severity. It was also in line with the previous studies that the soybean plant infected by CpMMV underwent the decline of vegetative and generative growth (Sutrisno and Kuswantoro 2016; Zubaidah and Kuswantoro 2017). If the process of flowering is destructed, the process of pod forming and seed ripening will be destructed as well so that it influences the soybean seed yield (Table 1). 
Table 1. Correlation coefficient value of the agronomical character to the seed yield of soybean promising lines infected by CpMMV

\begin{tabular}{|c|c|c|c|c|c|c|c|c|c|c|c|c|c|c|}
\hline & & $\mathrm{X} 2$ & $\mathbf{X 3}$ & $\mathrm{X4}$ & $\mathrm{X5}$ & X6 & $\mathbf{X 7}$ & X8 & X9 & $\mathbf{X 1 0}$ & X11 & $\mathrm{X} 12$ & $\mathbf{X 1 3}$ & X14 \\
\hline \multirow[t]{2}{*}{$\overline{X 1}$} & $\mathbf{r}_{\mathrm{g}}$ & 0.345 & 0.237 & 0.195 & 0.008 & 0.023 & 0.366 & 0.048 & 0.212 & $-0.763^{* *}$ & 0.150 & $0.592 *$ & 0.067 & -0.333 \\
\hline & $\mathbf{r}_{\mathbf{p}}$ & $0.498 *$ & 0.209 & 0.351 & 0.457 & 0.040 & $0.683^{* *}$ & 0.313 & 0.163 & $-0.707 * *$ & $0.498^{*}$ & $0.649 *$ & 0.052 & $-0.541^{*}$ \\
\hline \multirow[t]{2}{*}{$\mathrm{X} 2$} & $\mathbf{r}_{\mathrm{g}}$ & & 0.100 & $0.994 * *$ & 0.461 & 0.090 & $0.661^{* *}$ & $0.808^{* *}$ & 0.081 & 0.370 & 0.330 & 0.436 & 0.032 & $0.574^{*}$ \\
\hline & $\mathbf{r}_{\mathbf{p}}$ & & 0.099 & $0.997 * *$ & $0.584^{*}$ & 0.114 & 0.488 & $0.914 * *$ & 0.075 & 0.271 & 0.381 & 0.208 & 0.027 & -0.398 \\
\hline \multirow[t]{2}{*}{$\mathbf{X 3}$} & $\mathbf{r}_{\mathrm{g}}$ & & & 0.072 & 0.019 & 0.008 & 0.102 & 0.013 & 0.424 & 0.102 & 0.173 & 0.244 & 0.135 & -0.084 \\
\hline & $\mathbf{r}_{\mathbf{p}}$ & & & 0.049 & 0.043 & 0.011 & 0.106 & 0.077 & $0.526^{*}$ & 0.325 & 0.211 & 0.444 & 0.178 & -0.211 \\
\hline \multirow[t]{2}{*}{ X4 } & $r_{g}$ & & & & 0.386 & 0.239 & 0.483 & 0.227 & 0.035 & 0.349 & 0.298 & 0.412 & 0.011 & 0.404 \\
\hline & $\mathbf{r}_{\mathbf{p}}$ & & & & $0.502 *$ & $0.543^{*}$ & 0.431 & $0.862 * *$ & 0.052 & 0.263 & 0.364 & 0.225 & 0.017 & 0.329 \\
\hline \multirow[t]{2}{*}{ X5 } & $\mathbf{r g}_{\mathrm{g}}$ & & & & & 0.374 & 0.165 & 0.259 & 0.010 & 0.153 & 0.105 & 0.181 & 0.001 & -0.244 \\
\hline & $\mathbf{r}_{p}$ & & & & & $0.521^{*}$ & 0.238 & 0.456 & 0.032 & 0.157 & 0.203 & 0.132 & 0.012 & -0.459 \\
\hline \multirow[t]{2}{*}{ X6 } & $\mathbf{r g}_{\mathrm{g}}$ & & & & & & 0.057 & 0.123 & 0.007 & 0.034 & $0.522 *$ & 0.039 & 0.001 & 0.220 \\
\hline & $\mathbf{r}_{p}$ & & & & & & 0.056 & 0.106 & 0.009 & 0.031 & 0.943 & 0.026 & 0.003 & 0.037 \\
\hline \multirow[t]{2}{*}{ X7 } & $r_{g}$ & & & & & & & 0.132 & 0.021 & $-0.675^{* *}$ & $0.614^{*}$ & $0.746^{* *}$ & 0.013 & 0.195 \\
\hline & $\mathbf{r}_{\mathbf{p}}$ & & & & & & & 0.348 & 0.082 & $-0.559 *$ & $0.821 * *$ & 0.465 & 0.036 & $0.549^{*}$ \\
\hline \multirow[t]{2}{*}{$\mathrm{X8}$} & $\mathbf{r}_{\mathrm{g}}$ & & & & & & & & -0.004 & 0.348 & 0.328 & 0.302 & -0.008 & $0.869^{* *}$ \\
\hline & $\mathbf{r}_{\mathbf{p}}$ & & & & & & & & 0.041 & -0.294 & 0.425 & 0.243 & 0.017 & 0.221 \\
\hline \multirow[t]{2}{*}{ X9 } & $\mathbf{r g}_{\mathrm{g}}$ & & & & & & & & & 0.209 & 0.206 & 0.150 & 0.017 & 0.055 \\
\hline & $\mathbf{r}_{\mathbf{p}}$ & & & & & & & & & 0.283 & 0.185 & 0.336 & 0.062 & 0.488 \\
\hline \multirow[t]{2}{*}{ X10 } & $\mathbf{r}_{\mathrm{g}}$ & & & & & & & & & & $-0.715^{* *}$ & $0.802 * *$ & 0.076 & -0.286 \\
\hline & $\mathbf{r}_{\mathbf{p}}$ & & & & & & & & & & $-0.562 *$ & $0.834 * *$ & 0.102 & $-0.559^{*}$ \\
\hline \multirow[t]{2}{*}{ X11 } & $\mathbf{r g}_{\mathrm{g}}$ & & & & & & & & & & & $-0.867^{* *}$ & 0.058 & 0.313 \\
\hline & $\mathbf{r}_{\mathbf{p}}$ & & & & & & & & & & & $-0.572 *$ & 0.060 & $0.822 * *$ \\
\hline \multirow[t]{2}{*}{ X12 } & $\mathbf{r}_{\mathrm{g}}$ & & & & & & & & & & & & 0.071 & 0.262 \\
\hline & $\mathbf{r}_{\mathbf{p}}$ & & & & & & & & & & & & 0.124 & 0.479 \\
\hline \multirow[t]{2}{*}{ X13 } & $\mathbf{r}_{\mathrm{g}}$ & & & & & & & & & & & & & 0.003 \\
\hline & $\mathbf{r}_{\mathbf{p}}$ & & & & & & & & & & & & & 0.002 \\
\hline
\end{tabular}

Note: $\mathrm{X} 1=$ flowering period, $\mathrm{X} 2=$ days to maturity, $\mathrm{X} 3=$ plant height, $\mathrm{X} 4=$ leaf length, $\mathrm{X} 5=$ leaf width, $\mathrm{X} 6=$ leaf ratio, $\mathrm{X} 7=$ number of reproductive nodes, $\mathrm{X} 8=$ number of branches, $\mathrm{X} 9=$ number of filled pods, $\mathrm{X} 10=$ number of unfilled pods, $\mathrm{X} 11=100$ seeds weight, $\mathrm{X} 12$ = disease severity, $\mathrm{X} 13=$ number of seeds per plant, $\mathrm{X} 14=$ seed yield per plant, $\mathrm{r}_{\mathrm{g}}=$ genotypic correlation, $\mathrm{r}_{\mathrm{p}}=$ phenotypic correlation, $*=$ significance at $0.05, * *=$ significance at 0.01

The number of reproductive nodes had a positive phenotypic correlation to the seed yield per plant, and 100 seeds weight had a significant positive phenotypic correlation to the seed yield per plant. The character of days to maturity had a significant and positive genotypic correlation to the seed yield per plant. The number of branches had a significant positive genotypic correlation to the seed yield per plant. The positive value shown by those characters had an in line correlation to the seed yield. It means that the increase in the number of reproductive nodes, the 100 seeds weight, the days to maturity, and the number of branches was followed by the increase in the seed yield per plant. This results were also in line with the research conducted by Kobraee and Shamsi (2011), Alakhder et al. (2015), Islam and Rai (2013) and ElMohsen et al. (2013) showing that the number of reproductive nodes, 100 seeds weight, the days to maturity, and the number of branches had a significant and positive correlation the seed yield per plant (Table 1).

\section{Direct effect}

The result of path analysis showed that the main characters that gave significant positive direct effect to the seed yield per plant were the number of reproductive nodes, the 100 seeds weight and the number of seeds per plant. The path coefficient $(\mathrm{P})$ of each character were $0.256,0.323$ and 0.896 , respectively. The three characters had a direct and high correlation (Table 2). Selection of the seed yield per plant can be based on these three characters. These analysis results were in line with the results of Ramírez and Gustavo (2012) and Silva et al. (2015). Based on the path analysis, the number of reproductive nodes, the 100 seeds weight had a significant direct effect on the seed yield per plant. Yucel (2003) reported that the character having the highest direct effect to the seed yield was the number of seeds per plant.

The characters of the days to flowering, days to maturity, plant height, leaf length, leaf width, leaf ratio, and the number of unfilled pods showed a negative direct effect to the seed yield per plant (Table 2). The path coefficient of those characters were $-0.245,-0.023,-0.134,-0.113,-0.108$ and -0.017 , respectively. The low positive direct effects to the seed yield per plant were the disease severity, the number of filled pods, the number of branches and the leaf length. The values of path coefficient of those characters were $0.012,0.025,0.060$ and 0.162 , respectively. Those characters as the selection criteria can be regarded unimportant since they were less useful to the seed yield per plant. The study of Islam and Rai (2013), Mahbub et al. (2015), and Harriman (2016) also showed the days to flowering, the days to maturity, the plant height, the number of branches, the number of unfilled pods showed low negative direct effect to the seed yield per plant. 
Table 2. The direct and indirect effect of agronomical character to the seed yield of soybean promising lines infected by CpMMV

\begin{tabular}{|c|c|c|c|c|c|c|c|c|c|c|c|c|c|c|}
\hline \multirow{2}{*}{$(\mathbf{X i})$} & \multirow[t]{2}{*}{ b) } & \multicolumn{13}{|c|}{ Indirect effect through } \\
\hline & & $\mathbf{X 1}$ & $\mathbf{X 2}$ & $\mathbf{X 3}$ & $\mathrm{X4}$ & $\mathbf{X 5}$ & X6 & $\mathbf{X 7}$ & $\mathbf{X 8}$ & $\mathbf{X 9}$ & $\mathbf{X 1 0}$ & $\mathbf{X 1 1}$ & $\mathbf{X 1 2}$ & $\mathbf{X 1 3}$ \\
\hline$\overline{X 1}$ & 245 & - & 0.008 & 0.048 & 0.087 & 0.057 & 0.002 & 0.040 & 025 & 0.012 & 0.005 & 0.214 & 0.001 & 0.513 \\
\hline $\mathrm{X} 2$ & & 08 & - & .007 & 0. & 00 & & & & & .002 & & 003 & 030 \\
\hline X3 & & & -0.001 & - & 0.089 & -0.053 & & & & & 07 & & 002 & .496 \\
\hline X4 & 162 & 1 & -0.001 & -0.073 & 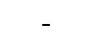 & -0.072 & -0.044 & & 27 & & 04 & & -0.001 & .561 \\
\hline X5 & & 3 & -0.000 & -0.062 & 0.103 & . & 0.048 & 0.122 & 0.028 & 14 & 0.005 & & -0.001 & 0.484 \\
\hline X6 & & -0.006 & -0.002 & -0.012 & 0.065 & 0.050 & 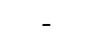 & -0.022 & -0.001 & 0.001 & -0.001 & & 0.000 & 0.071 \\
\hline $\mathbf{X} 7$ & & -0.038 & -0.004 & -0.102 & 0.068 & -0.054 & 0.009 & 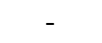 & 0.032 & 0.018 & 0.003 & & 0.001 & 0.536 \\
\hline X8 & & -0.100 & -0.003 & -0.057 & 0.073 & -0.052 & 0.002 & 0.137 & 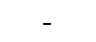 & 0.017 & 0.001 & -0.054 & -0.001 & 0.580 \\
\hline X9 & 025 & -0.113 & -0.000 & -0.079 & 0.096 & 0.062 & -0.002 & 0.184 & 0.040 & - & 0.004 & -0.077 & -0.001 & 0.817 \\
\hline $\mathrm{X} 10$ & 01 & 0.070 & -0.002 & 0.055 & -0.041 & 0.034 & -0.005 & -0.052 & -0.004 & -0.006 & 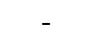 & 0.151 & 0.001 & -0.231 \\
\hline X11 & & 0.163 & 0.003 & 0.044 & -0.050 & 0.048 & -0.017 & -0.027 & -0.010 & -0.006 & -0.008 & - & 0.000 & -0.373 \\
\hline X12 & & 0.023 & 0.006 & -0.017 & -0.007 & 0.006 & -0.001 & 0.018 & -0.004 & -0.002 & -0.001 & 0.008 & - & -0.043 \\
\hline $\mathrm{X} 13$ & 0.896 & -0.140 & -0.001 & -0.074 & -0.101 & -0.061 & -0.009 & 0.153 & 0.039 & 0.022 & 0.004 & -0.134 & -0.001 & 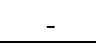 \\
\hline
\end{tabular}

Note: $\mathrm{X} 1=$ flowering period, $\mathrm{X} 2=$ days to maturity, X3= plant height, $\mathrm{X} 4=$ leaf length, $\mathrm{X} 5=$ leaf width, X6 = leaf ratio, X7= number of reproductive nodes, $\mathrm{X} 8=$ number of branches, $\mathrm{X} 9=$ number of filled pods, $\mathrm{X} 10=$ number of unfilled pods, $\mathrm{X} 11=100$ seeds weight, $\mathrm{X} 12=$ disease severity, $\mathrm{X} 13=$ number of seeds per plant, $\mathrm{P}=$ direct effect

\section{Indirect effect}

The direct effect of agronomical character to the seed yield is related to the role of the other agronomical characters having the indirect effect on the seed yield. The indirect effect of the number of filled pods through the number of seeds per plant showed high positive value (Table 2). It means that the number of seeds per plant had a significant role in increasing the seed yield per plant. These research results were in line with the research results of Mahbub et al. (2015) showed that the number of filled pods through the number of seeds per plant gave the significant indirect effect to the seed yield per plant. The similar results also reported by Silva et al. (2015) that number of pods per plant through the number of seeds per plant showed high indirect effetc. It was in accordance with the high and positive value of the correlation coefficient of the number of filled pods to the number of seeds per plant (Table 1).

The indirect effect of the days to flowering, plant height, leaf length, leaf width, the number of reproductive nodes, the number of branches, and number of filled pods through the number of seeds per plant had the high positive value as well (Table 2). Akram et al. (2016) also reported the high indirect effect of number of branches and number of pods per plant through the number of seeds per plant. However, El-Badawy and Mehasen (2012) reported that plant height, number of branches, and number of pods per plant through the number of seeds per plant showed low indirect effect. Varnica et al. (2018) reported different results that plant height and day to flowering showed low indirect effect through number of seed per plant, while the number of pods per plant showed high indirect effect through number of seed per plant. Of those seven characters, two characters, i.e. number of reproductive nodes and number of branches, had a significant phenotypic and genotypic correlation to the seed yield respectively (Table 1). Machado et al. (2017) also reported that number of branches had significant genotypic and phenotypic correlation to seed yield. These two characters had a important role in the increase of seed yield per plant. Besides, the environment factor also influenced the seed yield. The indirect effect through the other characters did not show a significant value since it was small or negative. The number of reproductive nodes had significant correlation and high direct effect on the seed yield per plant. These characters can be the selection criteria to get the high production of soybean which is resistant to CpMMV (Table 2).

In conclusion, the number of reproductive nodes and the 100 seeds weight had a significant positive phenotypic correlation to the seed yield per plant. The days to maturity and the number of branches had a significant and positive genotypic correlation to the seed yield per plant. The number of reproductive nodes, the 100 seeds weight, and the number of seeds per plant had a high direct effect on the seed yield per plant. The indirect effect of the number of filled pods, days to flowering, plant height, leaf length, leaf width, the number of reproductive nodes, and the number of branches through the number of seeds per plant was also highly positive. Hence, number reproductive nodes and 100 seeds weight can be select as selection criteria for high yielding CpMMV resistant soybean lines.

\section{ACKNOWLEDGMENTS}

The publication of this article is funded by DRPM DIKTI for the higher education basic research grant funding No. 1.3.44/un32.14/lt/2018.

\section{REFERENCES}

Agudamu, Yoshihira T, Shiraiwa T. 2016. Branch development responses to planting density and yield stability in soybean cultivars. Plant Production Science 19 (3): 331-339.

Alakhder HH, Zeinab EG, Rabie EM. 2015. Evaluation some genotypes of soybeans yield under pest infestation. In: Future of Water, Energy, 
Climate and Food Nexus in the Arab Countries. Intl J Sci Res Agric Sci (Proc) 2: 7-17.

Almeida AMR, Piuga FF, Marim SRR, Kitajima EW, Gaspar JO, Oliveira TG, Moraes TG. 2005. Detection and Partial characterization of a carlavirus causing stem necrosis of soybean in Brazil. Fitopatologia Brasileira 30: 191-194.

Akram S, Hussain BMN, Bari MAA, Burritt DJ, Hossain MA. 2016. Genetic variability and association analysis of soybean (Glycine $\max ($ L.) Merrill) for yield and yield attributing traits. Plant Gene and Trait 7 (13): 1-11. DOI: 10.5376/pgt.2016.07.0013

Arias CAA, Almeida AMR, Mituti T, Kitajima EW. 2015. Inheritance of tolerance to Cowpea Mild Mottle Virus in soybean. Crop Breed App Biotechnol 15 (3): 132-138. DOI: 10.1590/1984-70332015v15n3a24

Arshad M, Naazar A, Abdul G. 2006. Character correlation and path coefficient. In Soybean Glycine Max (L.) Merrill. Pak. J. Bot 38 (1) 121-130.

Balla MY, Ibrahim SE. 2017. Genotypic correlation and path coefficient analysis of soybean [Glycine $\max$ (L.) Merr.] for yield and its components. Agric Res Tech 7 (3): 555715. DOI 10.19080/ARTOAJ.2017.07.555715

Barbosa RP, Neto FA, Gravina LM, Gravina GA, Portela MGT, Bezerra AAC. 2016. Early selection of sugarcane using path analysis. Genet Mol Res 16 (1): gmr16019038. DOI: 10.4238/gmr16019038

Chen Y, Nelson RL. 2004. Evaluation and classification of leaflet shape and size in wild soybean. Crop Sci. 44: 671-677.

El-Badawy MEM, and Mehasen SAS. 2012. Correlation and path coefficient analysis for yield and yield components of soybean genotypes under different planting density. Asian J. Crop Sci. 4: 150158.

El-Mohsen AAA, Mahmoud GO, Safina SA. 2013. Agronomica evaluation of six soybean cultivars using correlation and regression analysis under different irrigation regime conditions. J. Plant Breed. Crop Sci. 5 (5): 91-102.

Fehr WR, Caviness CL. 1977. Stages of Soybean Development. Special Report No. 80. Cooperative Extention Services Agric. and Home Econ. Exp. St. Iowa State Univ. of Sci. and Tech., Ames. Iowa.

Gardner FP, Pearce RB, RL Mitchell RL. 1991. Physiology of Crop Plants. Iowa State Univ. Press, Iowa.

Harriman CJ, Abraham AN, Chuka CO, Nonso KN. 2016. Influence of genotype on the expression of host plant resistance in soybean (Glycine $\max (\mathrm{L}$.) Merrill) to the major insect pests of soybean in Umudike. The Journal of Middle East and North Africa Sciences 2 (2): 48-55.

Hartman GL, Chang HX, Leandro LF. 2015. Research advances and management of soybean sudden death syndrome. Crop Protect 73: 60 66. https: //doi.org/10.1016/j.cropro.2015.01.017

Hobbs HA, Hill CB, Grau CR, Koval NC, Wang Y, Pedersen WL, Domier LL, Hartman GL. 2006. Green stem disorder of soybean. Plant Dis. 90 (4): 513-518

Iletri. 2017. Description of Soybean Superior Varieties 1918-2016 Indonesian Legume and Tuber Crops Research Institute, Malang. [Indonesian]

Islam AKM, Rai PK. 2013. Character association of soybean (Glycine $\max$ ) lines for yield contributing traits. Bangladesh J. Pl. Breed. Genet 26 (2): 33-38.

Kobraee S, Shamsi K. 2011. Evaluation of soybean yield under drought stress by path analysis. Austr J Basic Appl Sci 5 (10): 890-895.

Kuswantoro H, Sutrisno, Han WY, Lee PY, Cho YH, Baek IY. 2014 Performance of Korean soybean varieties in Indonesia. Korean J. Int Agric. 26 (2): 107-113

Kuswantoro H, Zubaidah S, Saleh N. 2008. Performance of soybean genotypes from East Java to CpMMV infestation. In Harsono A Taufiq A, Rahmianna AA, Suharsono, Rozy F, Wijanarko A Widjono A, Soehendy R. Innovation Technology of Legume and Tuber Crops Supporting Food Sufficiency and Energy Availability.
Seminar of Research Results of Legume and Tuber Crops 2007. [Indonesian].

Kuswantoro H, Zubaidah S, Sulisetijono. 2014. Decreasing grain size caused declining grain yield of cpmmv-resistant soybean lines grown in Ultisols. J Biol Sci 14 (8): 508-514.

Laguna IG, Arneodo JD, Rodriguez-Pardina P, Fiorona M. 2006. Cowpea mild mottle virus infecting soybean crops in North-Western Argentina. Fitopatologia Brasileira31: 317.

Machado BQV, Nogueira APO, Hamawaki OT, Rezende GF, Jorge GL, Silveira IC, Medeiros LA, Hamawaki RL, Hamawaki CDL. 2017. Phenotypic and genotypic correlations between soybean agronomic traits and path analysis. Genet Mol Res 16 (2): gmr16029696. DOI: 10.4238 /gmr16029696.

Mahbub MM, Rahman MM, Hossain MS, Mahmud M, Mir Kabir MM. 2015. Genetic variability, correlation and path analysis for yield and yield components in soybean. Amer-Eur J. Agric. Environ. Sci 15 (2): 231-236.

Menzel W, Winter S, Vetten H. 2010. Complete nucleotide sequence of the type isolate of Cowpea mild mottle virus from Ghana. Arch Virol 155: 2069-2073.

Naidu RA, Gowda S, Satyanarayana T, Boyko V, Reddy AS, Dawson WO, Reddy DVR. 1998. Evidence that whitefly-transmitted cowpea mild mottle virus belongs to the genus Carlavirus. Arch Virol 143: 769-780.

Norsworthy JK, Shipe ER. 2005. Effect of row spacing and soybean genotype on mainstem and branch yield. Agron J. 97 (3): 919-923.

Ramírez RAV, Gustavo ALM. 2012. Phenotypic correlation and path analysis for yield in soybean (Glycine $\max$ (L.) Merril). Acta Agronómica. 61 (4): 322-332.

Rodrigues JCV, Kondidie DB, Estevez-Jensen C, Kitajima EW, Huckaba RM, Foster JE. 2014. Infection in soybeans and on multiple host plants in Puerto Rico by an isolate of cowpea mild mottle virus. Virus Rev Res. 19: 1-5.

Silva AF, Sediyama T, Silva FCS, Bezerra ARG, Ferreira LV. 2015. Correlation and path analysis of soybean yield components. Int. J. Plant Anim. Environ. Sci. 5 (1): 177-179.

Sinclair JB. 1993. Compendium of Soybean Diseases. Sec. Ed. The American Phytopathology Society. St. Paul. MN.

Singh RK, BD Chaudhary. 1979. Biometrical Methods in Quantitative Genetic Analysis. Kalyani Pub. Ludhiana, New Delhi

Sutrisno, Kuswantoro H. 2016. Cowpea mild mottle virus (CpMMV) infection and its effect on performance of South Korean soybean varieties. Biodiversitas 17 (1): 129-133.

Varnica I, Petrović S, Rebekić A, Guberac S, Jukić K. Jukić G. 2018. Characterization and interrelationships of soybean [Glycine max (L.) Merrill] yield components during dry and humid seasons. J. Central European Agric. 19 (2): 466-481.

Yucel C. 2003. Correlation and path coefficient analyses of seed yield components in the narbon bean (Vicia narbonensis L.) Turk J Agric For 28: 371-376.

Zanardo LG, Silva FN, Bicalho AAC, Urquiza GPC, Lima ATM, Almeida AMR, Zerbini FM, Carvalho CM. 2014. Molecular and biological characterization of cowpea mild mottle virus isolates infecting soybean in Brazil and evidence of recombination. Plant Pathol 63: 456-465.

Zanardo LG. 2017. New insights of cowpea mild mottle virus (CpMMV) infection. In Soybean: The Involvement of Viral Replicase In Symptoms Induction and Its Interaction With Host Factors. Viçosa. Minas Gerais, Brasil.

Zubaidah S, Kuswantoro H. 2017. Foliar symptoms recovery: developing scoring technique for assessment of soybean resistance to CpMMV (cowpea mild mottle virus). J Biol Res 21 (2): 85-89.

Zubaidah S, Kuswantoro H. 2006. Identification of RAPD Molecular Marker for Soybean Germplasm Resistant to CpMMV (cowpea mild mottle virus). Report on Fundamental Research Results. Universitas Negeri Malang, Malang. [Indonesian] 